\title{
Glimepiride monotherapy in achieving good blood glucose control in type-2 diabetes mellitus: a prospective observational study
}

\author{
Kris Pranarka ${ }^{1}$, Arini Setiawati ${ }^{2}$, Samsirun Halim ${ }^{3}$, Dian Saraswati ${ }^{4}$, Zulkifli Alkaf ${ }^{5}$ \\ ${ }^{1}$ Private Clinic, Semarang \\ ${ }^{2}$ Department of Pharmacology and Therapeutics - Faculty of Medicine, University of Indonesia, Jakarta \\ ${ }^{3}$ Private Clinic, Jambi \\ ${ }^{4}$ Gatoel Hospital, Mojokerto \\ ${ }^{5}$ Private Clinic, Medan
}

\begin{abstract}
Abstrak
Tujuan Glimepirid adalah suatu antihiperglikemia golongan sulfonilurea untuk terapi oral diabetes melitus tipe 2. Studi ini dilakukan untuk menilai glimepirid monoterapi dalam mengendalikan gula darah (HbA $A_{1}$ pada pasien DM tipe 2, dosis yang digunakan, dan profil keamanannya.

Metode Studi observasional prospektif ini dilakukan di 4 klinik pribadi di Semarang, Jambi, Mojokerto dan Medan antara Oktober 2006 sampai September 2007 pada pasien rawat jalan, pria dan wanita, umur >20 tahun, dengan DM tipe 2, $\mathrm{Hb}_{1 \mathrm{l}}>7 \%$, dan tidak mendapat antidiabetik oral paling sedikit 3 bulan sebelumnya. Tablet glimepirid diberikan sekali sehari selama 3 bulan.

Hasil Dari 74 pasien yang memenuhi syarat, 18 pasien tidak kembali untuk evaluasi dan 56 pasien menyelesaikan studi 3 bulan ini, terdiri dari 26 pasien baru (belum pernah mendapat obat antidiabetes) dan 30 pasien yang sebelumnya pernah diobati (dengan obat antidiabetes). Dosis glimepirid awal dan akhir tidak berbeda untuk pasien baru maupun pasien yang sebelumnya pernah diobati (awal 2,0 mg, akhir 2,3 mg). Penurunan rata-rata kadar Hb ${ }_{1 c} 1,8 \%$ untuk semua pasien, lebih besar pada pasien baru (2,3\%) dibandingkan dengan pasien yang sebelumnya pernah diobati (1,3\%). Berdasarkan berat massa tubuh, penurunan rata-rata kadar HbA1c pada 20 pasien dengan BB normal 1,3\%, dan lebih besar pada 20 pasien obese $(2,4 \%)$. Penurunan rata-rata kadar gula darah puasa pada semua pasien 54 $\mathrm{mg} / \mathrm{dL}$, lebih besar pada pasien baru $(83 \mathrm{mg} / \mathrm{dL}$ ) dibandingkan pasien yang pernah diobati (30 $\mathrm{mg} / \mathrm{dL})$, tetapi tidak dipengaruhi oleh berat badan. Berat badan meningkat selama studi dengan rerata $0.9 \mathrm{~kg}$. Tidak ada efek samping yang dialami oleh pasien selama 3 bulan monoterapi dengan glimepirid pada studi ini.
\end{abstract}

Kesimpulan Glimepirid monoterapi pada studi observasional dalam praktek sehari-hari selama 3 bulan ini efektif dalam menurunkan kadar $\mathrm{Hb}_{1 c}$ dan gula darah puasa, terutama pada pasien baru. Glimepirid pada studi ini disertai dengan peningkatkan berat badan meskipun tidak bermakna secara statistik. Tidak dilaporkan adanya efek samping dalam studi ini. (Med J Indones 2009; 18: 172-80)

\begin{abstract}
Aims Glimepiride is a sulphonylurea antihyperglycemic agent for oral therapy of type- 2 diabetes mellitus. This study was carried out to evaluate glimepiride monotherapy in controlling blood glucose $\left(\mathrm{HbA}_{1 \mathrm{c})}\right.$ in type-2 DM patients, its dosage, and safety profile.

Methods This was a prospective observational study carried out at 4 private clinics in Semarang, Jambi, Mojokerto and Medan between October 2006 and September 2007 in outpatients of both gender, aged $>20$ years, with type- $2 \mathrm{DM}, \mathrm{HbA}>7 \%$, and received no oral antidiabetic treatment for at least 3 months. Glimepiride tablet was given once daily for 3 months.

Results From 74 eligible patients, 18 patients were lost to follow-up and 56 patients completed this 3 months study, consisting of 26 treatment-naive patients and 30 previously treated patients. The initial and final doses of glimepiride were similar in both treatment-naive patients and previously treated patients (initial $2.0 \mathrm{mg}$, final $2.3 \mathrm{mg}$ ). The mean reduction of $\mathrm{HbA} 1 \mathrm{c}$ levels was $1.8 \%$ (absolute) for all patients, higher in naive patients $(2.3 \%)$ compared to previously treated patients $(1.3 \%)$. Based on BMI, the mean reduction of $\mathrm{HBA}_{1 \mathrm{c}}$ in 20 normal weight patients was $1.3 \%$, and more marked in 20 obese patients $(2.4 \%)$. The mean reduction of FBG levels in all patients was $54 \mathrm{mg} / \mathrm{dL}$, more pronounced in naive patients $(83 \mathrm{mg} / \mathrm{dL}$ ) compared to previously treated patients $(30 \mathrm{mg} / \mathrm{dL})$, but not affected by body weight. Bodyweight was increased during the study by a mean of $0.9 \mathrm{~kg}$. No adverse event was encountered in any patient during 3 months monotherapy with glimepiride in the present study.

Conclusion: Glimepiride monotherapy in the present observational study in daily practice for 3 months was shown to be effective in reducing $\mathrm{HbA}_{1 \mathrm{c}}$ and FBG levels, especially in treatment naive patients. Glimepiride in the present study was associated with weight gain, although not statistically significant. No adverse event was reported in the present study. (Med J Indones 2009; 18: 172-80)
\end{abstract}

Key words : glimepiride monotherapy, observational study, type-2 diabetes mellitus. 
Glimepiride is the latest second-generation sulphonylurea antihyperglycemic agent for oral therapy of type- 2 diabetes mellitus. Its main action is stimulating insulin release from pancreatic $\beta$-cells. ${ }^{1,2}$ Glimepiride binds to a $65 \mathrm{kD}$ submit of sulfonylurea receptor (SUR1) that forms a complex with an ATP-sensitive potassium channel called KIR 6.2 that is embedded in the pancreatic $\beta$-cell plasma membrane. Binding of the ligand sulfonylurea to SUR1 closes the KIR channel, resulting in membrane depolarization, which opens voltage-dependent calcium channels and leads to calcium influx into the cell., ${ }^{1,2}$ The elevated intracellular calcium levels trigger insulin secretion. It is a direct insulin secretagogue action; indirectly, it also increases insulin secretion in response to fuels such as glucose. ${ }^{2}$ In comparison to glibenclamide, glimepiride produces less marked hyperinsulinemia, causing a lower risk of hypoglycemia. ${ }^{2}$ Glimepiride enhances both the firstphase and the second-phase of insulin secretion. ${ }^{3}$

Glimepiride also has extrapancreatic actions. It improves the insulin sensitivity of peripheral tissues by increasing the number of glucose transporter molecules (GLUT1 and GLUT4) in the plasma membrane of muscle and adipose tissues and enhances their glucose uptake. ${ }^{1-4}$ Glimepiride significantly improved insulin resistance, suggested by a significant reduction of HOMA-IR (homeostasis model assessment of insulin resistance) ${ }^{5,6}$ Increased plasma adiponectin and decreased plasma TNF- $\alpha$ may underline the improvement of insulin resistance with glimepiride. ${ }^{5,6}$ Glimepiride also activates glycogenesis and lipogenesis, and inhibits hepatic gluconeogenesis. ${ }^{1,2,4}$ Both pancreatic (the increase in insulin secretion) and extrapancreatic (the improvement of glucose utilization) actions are responsible for the glucose-lowering properties of glimepiride..$^{1-4}$

After oral administration, glimepiride is completely absorbed, reaching peak plasma concentration at 2.4 to 3.8 hours in patients with type- 2 diabetes. The terminal elimination half-life of 1 to $8 \mathrm{mg}$ doses was 3.2 to 8.8 hours. $^{1}$

The usual initial dose is $1 \mathrm{mg}$ once daily. If necessary, based on regular blood sugar monitoring, the daily dose can be increased gradually at intervals of 1-2 weeks, and carried out stepwise to $2 \mathrm{mg}-3 \mathrm{mg}-4 \mathrm{mg}$, and in exceptional cases, $8 \mathrm{mg}$. The dose should be taken immediately before a substantial breakfast or, if none is taken, immediately before the first main meal. It is very important not to skip meals after taking glimepiride. ${ }^{7}$ This convenient once daily dosing may enhance com- pliance for diabetic patients who often also require medications for other co-morbid conditions. ${ }^{2}$

In comparison studies with equieffective doses of glibenclamide, glimepiride caused a lower incidence of hypoglycemia. ${ }^{8,9}$

The primary objective of the present observational study was to evaluate glimepiride monotherapy in controlling blood glucose in patients with type- 2 diabetes by examining $\mathrm{HbA}_{1 c}$ value. The other objectives were to evaluate the average glimepiride dosage used to achieve good blood glucose control, and to assess glimepiride safety profile and also patients' compliance.

\section{PATIENTS AND METHODS}

\section{Patients}

Male and female patients, aged 20 years or older, with type- 2 diabetes mellitus, $\mathrm{HbA}_{1 \mathrm{c}}$ more than $7 \%$, and received no oral antidiabetic treatment for the last 3 months or longer (treatment naive or previously treated) were eligible for the study. Patients with hypersensitivity to glimepiride or other sulfonylureas or other sulfonamides or any of the excipients of glimepiride tablet, pregnant women, nursing mothers, or women of childbearing potential without a reliable contraceptive measure, including postmenopausal women for less than 2 years, were excluded from the study. Patients participating in another investigational study were also excluded.

\section{Study design and procedure}

This was a prospective, observational study of patients with type-2 diabetes mellitus receiving glimepiride monotherapy for 3 months. The study was carried out at 4 private clinics in Semarang, Jambi, Mojokerto and Medan between 18 October 2006 and 29 September 2007.

Amaryl $^{\circledR}$ (glimepiride) was given once daily immediately before a substantial breakfast or the first main meal. The starting dose and the dose titration were decided by the physician based on patient's fasting blood glucose value (using glucometer at the physician office). The maximum permitted daily dose was $6 \mathrm{mg}$. The laboratory $\mathrm{HbA}_{1 \mathrm{c}}$ examination was done twice, at baseline and at the end of this 3 months study. There were 4 mandatory visits at month 0 (baseline visit, V1), 1 month (V2), 2 months (V3) and 3 months (end of study, V4). The in-between scheduled visits up to 3 months were arranged as necessary. 


\section{Assessments}

The primary efficacy variables in the present study were the changes of $\mathrm{HbA}_{1 \mathrm{c}}$ and fasting blood glucose (FBG) values from baseline at the end of 3 months treatment. The other variables to be assessed were the initial and the final doses of glimepiride of the naive patients and of the previously treated patients, and also the decreased in $\mathrm{HbA}_{1 \mathrm{c}}$ and $\mathrm{FBG}$ in those 2 groups of patients. The effects of BMI (normal, overweight, and obese) were also evaluated on the decrease in $\mathrm{HbA}_{1 \mathrm{c}}$, FBG, and body weight .

At the end of 3 months treatment, the percentages of patients reaching the target of $\mathrm{HbA}_{1 \mathrm{c}}(<7 \%)$ and of FBG $(<120 \mathrm{mg} / \mathrm{dL})$ were calculated and the reasons for not reaching the target were evaluated. The average glimepiride dose used and patients' compliance for taking glimepiride monotherapy were also evaluated.

The safety profile of glimepiride monotherapy was assessed in all patients taking this drug, even only 1 tablet, as long as he/she had at least once postbaseline visit.

\section{Data analyses}

Demographics and baseline characteristics were presented for all patients. Patients were then divided into 2 subgroups, the treatment naive patients and the previ- ously treated patients. For both subgroups, the decrease in $\mathrm{HbA}_{1 \mathrm{c}}$ and FBG were calculated, and also the initial and final doses of glimepiride. Then the patients were divided into 3 subgroups based on the BMI (the normal, the overweight, and the obese), and in each subgroup, the decrease in $\mathrm{HbA}_{1 \mathrm{c}}$, FBG and body weight were calculated. Lastly, the proportion of patients reaching target $\mathrm{HbA}_{1 \mathrm{c}}(<7 \%)$ and those reaching target FBG $(<120$ $\mathrm{mg} / \mathrm{dL}$ ) were calculated, and also patients' compliance was evaluated. All analyses were descriptive statistics.

Adverse events, considered related or unrelated by the physicians, were listed with their respective incidences.

\section{RESULTS}

\section{Patients}

A total of 74 patients were eligible for the study and received glimepiride at baseline visit. Eighteen patients were lost to follow-up at visits 2,3 , and $4(13,2$, and 3 patients, respectively), leaving 56 patients who completed this 3 months study and who were therefore evaluable for efficacy. No adverse events were noted for those patients who were lost to follow-up. The demographics and baseline characteristics of the 56 patients are presented in Table 1.

Table 1. Demographics and baseline characteristics of patients with type-2 DM who completed the study ( $\mathrm{n}=56$ )

\begin{tabular}{|c|c|c|c|c|c|c|}
\hline & \multicolumn{2}{|c|}{$\begin{array}{l}\text { All patients } \\
(n=56)\end{array}$} & \multicolumn{2}{|c|}{$\begin{array}{l}\text { Treatment-naive patients } \\
\qquad(n=26)\end{array}$} & \multicolumn{2}{|c|}{$\begin{array}{l}\text { Previously treated patients } \\
\qquad(\mathrm{n}=30)\end{array}$} \\
\hline & Mean (SD) & Range & Mean (SD) & Range & Mean (SD) & Range \\
\hline Gender: Male/Female & \multicolumn{2}{|c|}{$53.6 \% / 46.4 \%$} & \multicolumn{2}{|c|}{$50.0 \% / 50.0 \%$} & \multicolumn{2}{|c|}{$56.7 \% / 43.3 \%$} \\
\hline Age (years) & $53.0(9.27)$ & $32-78$ & $52.4(9.67)$ & $32-78$ & $53.5(9.04)$ & $38-74$ \\
\hline Weight (kg) & $61.1(11.49)$ & $43-108$ & $62.8(14.24)$ & $43-108$ & $59.8(8.75)$ & $48.5-86$ \\
\hline Height (cm) & $159.0(6.77)$ & $144-176$ & $158.9(7.45)$ & $144-176$ & $159.1(6.33)$ & $\_148-172$ \\
\hline BMI $\left(\mathrm{kg} / \mathrm{m}^{2}\right)$ & $24.0(3.63)$ & $18.0-34.9$ & $24.9(4.12)$ & $19.1-34.9$ & $23.6(2.92)$ & $18.0-31.6$ \\
\hline $\mathrm{HbA}_{1 \mathrm{c}}(\%)$ & $10.4(2.20)$ & $7.3-15.2$ & $10.8(2.35)$ & $7.3-15.2$ & $10.1(2.05)$ & _ $7.3-14.8$ \\
\hline FBG (mg/dL) & $224.0(89.74)$ & $107-559$ & $250.0(108.19)$ & $122-559$ & $201.6(63.71)$ & $107-379$ \\
\hline Duration of DM (months)* & - & - & - & - & $48.3(47.96)$ & $5-180$ \\
\hline \multicolumn{7}{|l|}{ Blood pressure $(\mathrm{mm} \mathrm{Hg})$} \\
\hline Systolic & $127.7(15.17)$ & $100-170$ & $126.1(16.02)$ & $100-160$ & $129.0(14.53)$ & $110-170$ \\
\hline Diastolic & $80.3(7.53)$ & $70-100$ & $81.0(8.49)$ & $70-100$ & 79.7 ( 6.69) & $70-100$ \\
\hline $\begin{array}{l}\mathrm{BMI}=\text { body mass index; } \\
\mathrm{HbA}_{1 \mathrm{c}}=\text { glycated hemoglobin }\end{array}$ & $\begin{array}{l}\mathrm{FBG}=\text { fastin } \\
\mathrm{SD}=\text { stand }\end{array}$ & $\begin{array}{l}\text { ng blood glucose } \\
\text { dard deviation }\end{array}$ & *since diagnosis & & & \\
\hline
\end{tabular}


There was a slightly higher prevalence of male than female patients ( $54 \%$ vs $46 \%$ ), while the mean age of all patients was 53.0 years. The mean $\mathrm{HbA}_{1 \mathrm{c}}$ was $10.4 \%$, the mean FBG was $224 \mathrm{mg} / \mathrm{dL}$, and the mean BMI was $24 \mathrm{~kg} / \mathrm{m} 2$ at baseline. The mean BP was 128/80 $\mathrm{mm} \mathrm{Hg}$ at baseline (Table 1). The mean BMI, $\mathrm{HbA}_{1 \mathrm{c}}$, and FBG were higher in treatment-naïve patients than in previously treated patients (Table 1).
Patients receiving high formal education were only $39.3 \%$. The obese patients were $35.7 \%$. The hypertensive, dyslipidemic and smoking (ever) patients were $25.0 \%, 30.4 \%$ and $20.1 \%$, respectively.

The newly diagnosed patients were 26 (46\%). Most of the previously ( $>3$ months) treated patients received sulfonylureas $(96.7 \%)$, and glibenclamide was the most common sulfonylureas prescribed (62.1\%) (Table 3).

Table 2. Education, BMI and other risk factors $(\mathrm{n}=56)$

\begin{tabular}{llll}
\hline & & $\mathrm{n}$ & $(\%)$ \\
\hline Education : & no formal & 4 & $(7.1)$ \\
& low formal & 30 & $(53.6)$ \\
& high formal & 22 & $(39.3)$ \\
BMI $\left(\mathrm{kg} / \mathrm{m}^{2}\right):$ & normal $(18-22.9)$ & 20 & $(35.7)$ \\
& overweight $(23-24.9)$ & 10 & $(17.9)$ \\
& obese $(\geq 25)$ & 20 & $(35.7)$ \\
& missing & 6 & $(10.7)$ \\
Hypertension (mmHg)* & 14 & $(25.0)$ \\
Dyslipidemia** & 17 & $(30.4)$ \\
Smoker (current and past ) & 12 & $(20.1)$ \\
\hline Fypre
\end{tabular}

* Hypertension is defined as SBP $>130 \mathrm{mmHg}$ or DBP $>85 \mathrm{mmHg}$

** Dyslipidemia is defined as total cholesterol $>200 \mathrm{mg} / \mathrm{dL}$ or LDL cholesterol $>100 \mathrm{mg} / \mathrm{dL}$ or $\mathrm{HDL}$ cholesterol $<45 \mathrm{mg} / \mathrm{dL}$ or triglycerides $>150 \mathrm{mg} / \mathrm{dL}$

Table 3. Previous antidiabetic therapy of patients who completed the study $(n=30)$

\begin{tabular}{cll}
\hline & $\mathrm{n}$ & \multicolumn{1}{c}{$\%$} \\
\hline Previously treated patients & 30 & 100.0 \\
- metformin & 1 & 3.3 \\
- sulfonylureas & 29 & 96.7 \\
- glibenclamide & 18 & 62.1 \\
- gliclazide & 2 & 6.9 \\
- glimepiride & 9 & 31.0 \\
\hline
\end{tabular}

Table 4. Doses of glimepiride in patients with type-2 DM who completed the study ( $\mathrm{n}=56$ )

\begin{tabular}{|c|c|c|c|c|c|}
\hline & \multirow[b]{2}{*}{$\mathrm{n}$} & \multicolumn{2}{|c|}{ Initial dose } & \multicolumn{2}{|c|}{ Final dose } \\
\hline & & Mean (SD) & Range & Mean (SD) & Range \\
\hline All patients & 56 & $2.0(0.6)$ & $1-3$ & $2.3(0.7)$ & $1-4$ \\
\hline Naive patients & 26 & $2.0(0.7)$ & $1-3^{*}$ & $2.3(0.8)$ & $1-4 \dagger$ \\
\hline Previously treated patients & 30 & $2.0(0.5)$ & $1-3^{* *}$ & $2.3(0.7)$ & $1-4 \dagger \dagger$ \\
\hline
\end{tabular}

$* 5,15$, and 6 patients received $1 \mathrm{mg}, 2 \mathrm{mg}$, and $3 \mathrm{mg}$, respectively

$* * 3,24$, and 3 patients received $1 \mathrm{mg}, 2 \mathrm{mg}$, and $3 \mathrm{mg}$, respectively

† 4, 12, 9, and 1 patient received $1 \mathrm{mg}, 2 \mathrm{mg}, 3 \mathrm{mg}$ and $4 \mathrm{mg}$, respectively

†† $1,21,6$, and 2 patients received $1 \mathrm{mg}, 2 \mathrm{mg}, 3 \mathrm{mg}$ and $4 \mathrm{mg}$, respectively 
The mean initial glimepiride dose for all patients was $2.0 \mathrm{mg}$ daily, which increased to $2.3 \mathrm{mg}$ daily, the final dose (at 3 months). The mean initial doses for naive patients and previously treated patients were similar, i.e. $2.0 \mathrm{mg}$ daily. The mean final doses were also similar, i.e. $2.3 \mathrm{mg}$ daily (Table 4).

For all patients, the mean (SD) decrease in $\mathrm{HbA}_{1 \mathrm{c}}$ after 3 months treatment was $1.8(2.3 \%)$. In naive patients, the decrease was $2.3 \%$, while in previously treated patients, it was $1.3 \%$. According to initial BMI, the mean (SD) decrease of $\mathrm{HbA} 1 \mathrm{c}$ in normal weight patients was $1.3(2.5 \%)$, but the decrease in obese patients was $2.4 \%$ (Table 5).
The mean (SD) decline in FBG after 3 months treatment for all patients was $54(83) \mathrm{mg} / \mathrm{dL}$. For naive patients, the decrease was $83 \mathrm{mg} / \mathrm{dL}$, and in previously treated patients, it was $30 \mathrm{mg} / \mathrm{dL}$. Based on the initial BMI, the mean (SD) decline of FBG in normal weight patients was 59 (79) $\mathrm{mg} /$ $\mathrm{dL}$, and in obese patients the decline was similar, i.e. 60 $\mathrm{mg} / \mathrm{dL}$ (Table 6).

After 3 months of therapy, the body weight of patients increased with a mean (SD) of 0.9 (2.2) $\mathrm{kg}$ (Table 7).

Table 5. HbA1c (\%) in patients with type-2 DM who completed the study ( $\mathrm{n}=56)$

\begin{tabular}{|c|c|c|c|c|c|c|c|}
\hline & \multicolumn{3}{|c|}{ Baseline } & \multicolumn{2}{|c|}{$\begin{array}{l}\text { End of treatment } \\
\text { ( } 3 \text { months })\end{array}$} & \multicolumn{2}{|c|}{$\begin{array}{l}\text { Difference } \\
\text { from baseline }\end{array}$} \\
\hline & $\mathrm{n}$ & Mean (SD) & Range & Mean (SD) & Range & Mean (SD) & Range \\
\hline All patients & 56 & $10.4(2.20)$ & $7.3-15.2$ & $8.6(2.18)$ & $6.0-17.3$ & $-1.8(2.30)$ & $-7.1 * 3.9$ \\
\hline Treatment-naive patients & 26 & $10.8(2.35)$ & $7.3-15.2$ & $8.5(2.38)$ & $6.6-17.3$ & $-2.3(2.58)$ & $-7.1 * 3.9$ \\
\hline Previously treated patients & 30 & $10.1(2.05)$ & $7.3-14.8$ & $8.8(2.03)$ & $6.0-13.1$ & $-1.3(1.95)$ & $-6.7 * 2.4$ \\
\hline Normal weight patients & 20 & $10.4(2.76)$ & $7.3-15.2$ & $9.1(2.79)$ & $6.2-17.3$ & $-1.3(2.54)$ & $-7.1 * 3.9$ \\
\hline Overweight patients & 10 & $9.6(1.91)$ & $7.3-13.7$ & $8.7(2.12)$ & $6.3-13.1$ & $-0.9(0.98)$ & $-2.4 * 0.6$ \\
\hline Obese patients & 20 & $10.6(1.86)$ & $8.3-13.6$ & $8.2(1.53)$ & $6.0-11.4$ & $-2.4(2.19)$ & $-6.7 * 0.4$ \\
\hline Missing & 6 & $(10.7 \%)$ & & & & & \\
\hline
\end{tabular}

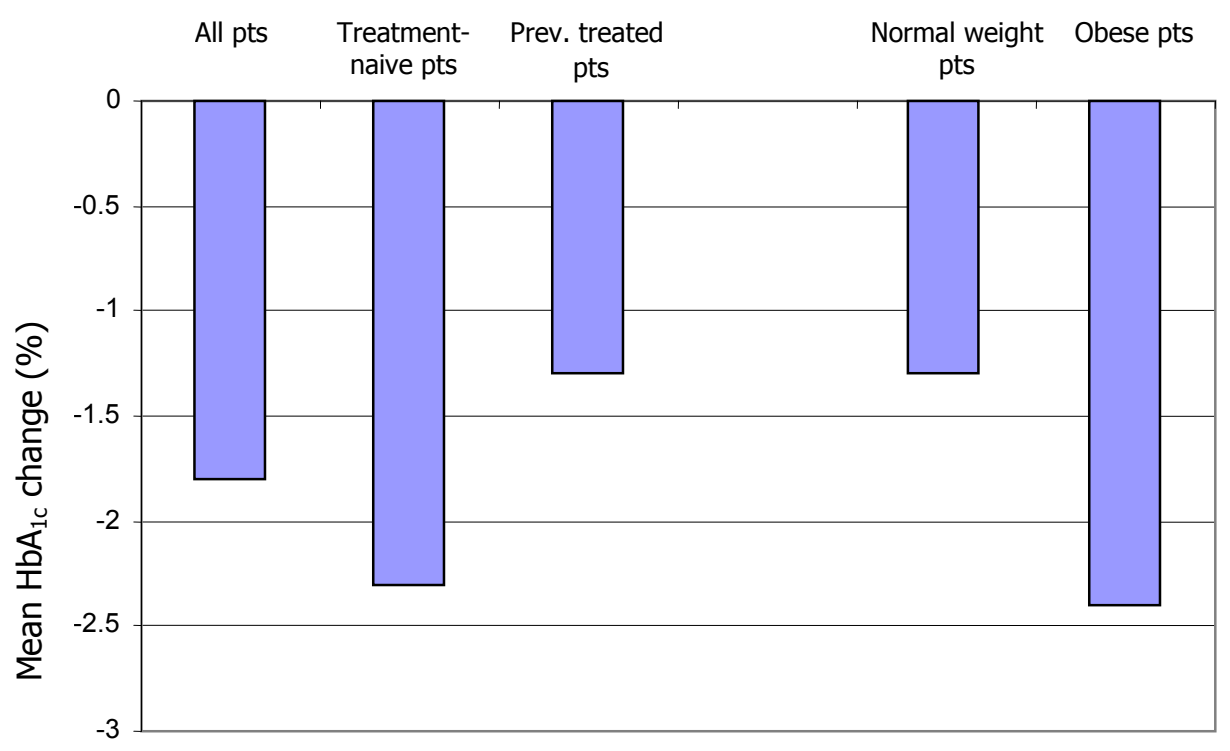

Figure 1. Mean HbAlc change in treatment-naive and previously treated patients, and in normal and obese patients. 
Table 6. FBG $(\mathrm{mg} / \mathrm{dL})$ in patients with type-2 DM who completed the study ( $\mathrm{n}=56)$

\begin{tabular}{|c|c|c|c|c|c|c|c|}
\hline & \multirow[b]{2}{*}{$\mathrm{n}$} & \multicolumn{2}{|c|}{ Baseline } & \multicolumn{2}{|c|}{$\begin{array}{c}\text { End of treatment } \\
\text { (3 months) }\end{array}$} & \multicolumn{2}{|c|}{$\begin{array}{c}\text { Difference } \\
\text { from baseline }\end{array}$} \\
\hline & & Mean (SD) & Range & Mean (SD) & Range & Mean (SD) & Range \\
\hline All patients & 56 & $224(89.7)$ & $107-559$ & $170(63.6)$ & $77-341$ & $-54(83.3)$ & $-259 * 120$ \\
\hline Treatment-naive patients & 26 & $250(108.2)$ & $122-559$ & $167(70.2)$ & $77-318$ & $-83(104.6)$ & $-259 * 111$ \\
\hline $\begin{array}{r}\text { Previously treated } \\
\text { patients }\end{array}$ & 30 & $202(63.7)$ & $107-379$ & $172(58.8)$ & $84-341$ & $-30(51.0)$ & $-127 * 120$ \\
\hline Normal weight patients & 20 & $232(107.9)$ & $107-559$ & $173(59.7)$ & $95-300$ & $-59(78.8)$ & $-259 \nrightarrow 76$ \\
\hline Overweight patients & 10 & $205(73.1)$ & $107-379$ & $169(76.3)$ & $96-341$ & $-36(52.5)$ & $-128 \rightarrow 31$ \\
\hline Obese patients & 20 & $223(82.8)$ & $122-476$ & $163(63.4)$ & $77-318$ & $-60(84.6)$ & $-246 * 111$ \\
\hline Missing & 6 & $(10.7 \%)$ & & & & & \\
\hline
\end{tabular}

Table 7. Body weight $(\mathrm{kg})$ in patients with type-2 DM who completed the study ( $\mathrm{n}=56$ )

\begin{tabular}{|c|c|c|c|c|c|c|c|}
\hline & \multirow[b]{2}{*}{$\mathrm{n}$} & \multicolumn{2}{|c|}{ Baseline } & \multicolumn{2}{|c|}{ At 3 months treatment } & \multicolumn{2}{|c|}{$\begin{array}{l}\text { Difference } \\
\text { from baseline }\end{array}$} \\
\hline & & Mean (SD) & $\overline{\text { Range }}$ & Mean (SD) & Range & Mean (SD) & Range \\
\hline All patients & 50 & $61.4(11.8)$ & $43-108$ & $62.3(11.9)$ & $42-108$ & $\pm 0.9(2.2)$ & $-5 \rightarrow+6$ \\
\hline Normal weight patients & 20 & $52.4(5.0)$ & $43-61$ & $53.8(5.9)$ & $42-66$ & $+1.4(2.1)$ & $-3 \rightarrow+6$ \\
\hline Overweight patients & 10 & $60.2(5.2)$ & $54-68.5$ & $59.4(5.0)$ & $50-66$ & $-0.8(2.1)$ & $-5 \rightarrow+2$ \\
\hline Obese patients & 20 & $71.1(11.6)$ & $55-108$ & $72.3(11.4)$ & $58-108$ & $+1.2(1.9)$ & $-2 \rightarrow+4$ \\
\hline Missing & 6 & $(10.7 \%)$ & & & & & \\
\hline
\end{tabular}

Table 8 . Patients reaching the target HbA1c $(<7 \%)$ among all patients with type-2 DM who completed the study $(\mathrm{n}=56)$

\begin{tabular}{lrl}
\hline & \multicolumn{1}{c}{ Yes } & No \\
& $\mathrm{n}(\%)$ & $\mathrm{n}(\%)$ \\
\hline All patients $(\mathrm{n}=56)$ & $12(21.4)$ & $44(78.6)$ \\
Treatment-naive patients $(\mathrm{n}=26)$ & $5(19.2)$ & $21(80.8)$ \\
Previously treated patients $(\mathrm{n}=30)$ & $7(23.3)$ & $23(76.7)$ \\
\hline Baseline $\mathrm{HbA}_{1 \mathrm{c}} 7-10 \%(\mathrm{n}=29)$ & $8(27.6)$ & $21(72.4)$ \\
$\quad$ Treatment-naive patients $(\mathrm{n}=12)$ & $2(16.7)$ & $10(83.3)$ \\
$\quad$ Previously treated patients $(\mathrm{n}=17)$ & $6(35.3)$ & $11(64.7)$ \\
\hline
\end{tabular}


After 3 months of therapy, patients reaching the target $\mathrm{HbA}_{1 \mathrm{c}}$ were 12 patients among a total of 56 patients (21.4\%), consisting of 5 patients among 26 treatmentnaive patients (19.2\%) and 7 patients among 30 previously treated patients (23.3\%) (Table 8). Among 29 patients with baseline $\mathrm{HbA}_{1 \mathrm{c}} 7-10 \%$, there were 8 patients $(27.6 \%)$ reached $\mathrm{HbA}_{1 \mathrm{c}}<7 \%$, consisting of 2 patients among 12 treatment-naïve patients $(16.7 \%)$ and 6 patients among 17 previously treated patients (35.3\%) (Table 8 ).

Patients reaching the target FBG after 3 months of therapy were 10 patients among a total of 56 patients (18\%), consisting of 6 patients among 26 treatment-naive patients $(23 \%)$ and 4 patients among 30 previously treated patients (13.3\%) (Table 9).

The mean (range) initial glimepiride dose for patients reaching target $\mathrm{HbA}_{1 \mathrm{c}}$ was 2.1 (1-3) mg daily and the final dose was 2.0 (1-3) mg daily, while for patients not reaching target $\mathrm{HbAlc}$ the initial glimepiride dose was 2.0 (1-3) $\mathrm{mg}$ daily and the final dose was $2.4(1-4) \mathrm{mg} /$ day.
Reasons for not reaching the $\mathrm{HbA} 1 \mathrm{c}$ and FBG target at the end of study (3 months) were:

Poor diabetic education $\quad 31(55.3 \%)$

Dosage not optimum $19(33.9 \%)$

Noncompliance to all antidiabetic therapies $6(10.7 \%)$

Weight concern $3(5.4 \%)$

Fear of hypoglycemia $\quad 2(3.6 \%)$

Concomitant illness $\quad 1(1.8 \%)$

Other $2(3.6 \%)$

Missing 3 ( $5.4 \%)$

The predominant reason for not reaching the target blood glucose was poor diabetic education (in 31 patients or $55 \%$ of all patients)

The mean systolic blood pressure decreased by $3.4 \mathrm{~mm}$ $\mathrm{Hg}$ and mean diastolic blood pressure by $0.7 \mathrm{~mm} \mathrm{Hg}$.

No adverse event, including hypoglycemia, was encountered during 3 months monotherapy with glimepiride in the present study. Discontinuation rate was 18 patients from 74 patients originally enrolled in the present study. These 18 patients were all lost to follow up without any explanation noted in the case report forms. No AEs were reported for these 18 patients.

Table 9. Patients reaching the target FBG $(<120 \mathrm{mg} / \mathrm{dL})$ among all patients with type-2 DM who completed the study ( $\mathrm{n}=56)$

\begin{tabular}{lrl}
\hline & Yes & No \\
& $\mathrm{n}(\%)$ & $\mathrm{n}(\%)$ \\
\hline All patients $(\mathrm{n}=56)$ & $10(17.9)$ & $46(82.1)$ \\
Naive patients $(\mathrm{n}=26)$ & $6(23.1)$ & $20(76.9)$ \\
Previously treated patients $(\mathrm{n}=30)$ & $4(13.3)$ & $26(86.7)$ \\
\hline
\end{tabular}

Table 10. Doses of glimepiride in patients reaching and not reaching the target HbA1c among all patients with type-2 DM who completed the study (n=56)

\begin{tabular}{lcccccc}
\hline & \multirow{n}{*}{} & \multicolumn{2}{c}{$\mathrm{HbA}_{1 \mathrm{c}}(\%)$} & & \multicolumn{2}{c}{ Daily dose (mg) } \\
& & $\begin{array}{c}\text { baseline } \\
\text { mean (range) }\end{array}$ & $\begin{array}{c}\text { final } \\
\text { mean (range) }\end{array}$ & & $\begin{array}{c}\text { baseline } \\
\text { mean (range) }\end{array}$ & $\begin{array}{c}\text { final } \\
\text { mean (range) }\end{array}$ \\
\hline Reach target $\mathrm{HbA}_{1 \mathrm{n}}$ & $12(21.4)$ & $9.68(7.3-13.6)$ & $6.60(6.0-6.9)$ & & $2.1(1-3)$ & $2.0(1-3)$ \\
Not reach target $\mathrm{HbA}_{1 \mathrm{n}}$ & $44(78.6)$ & $10.60(7.5-15.2)$ & $9.18(7.0-17.3)$ & & $2.0(1-3)$ & $2.4(1-4)$ \\
\hline
\end{tabular}

Table 11. Patients' compliance in taking glimepiride monotherapy

\begin{tabular}{llcc}
\hline & & Reach $\mathrm{HbA}_{1 \mathrm{c}}$ target & Not reach $\mathrm{HbA}_{1 \mathrm{c}}$ target \\
& & $12(100 \%)$ & $44(100 \%)$ \\
\hline $1^{\text {st }}$ month & $\geq 90 \%$ & $11(91.7 \%)$ & $32(72.7 \%)$ \\
& $50-89 \%$ & $1(8.3 \%)$ & $12(27.3 \%)$ \\
$2^{\text {nd }}$ month & $\geq 90 \%$ & $10(83.3 \%)$ & $30(68.2 \%)$ \\
& $50-89 \%$ & $1(8.3 \%)$ & $13(29.5 \%)$ \\
& Missing & $1(8.3 \%)$ & $1(2.3 \%)$ \\
$3^{\text {rd }}$ month & $\geq 90 \%$ & $11(91.7 \%)$ & $31(70.5 \%)$ \\
& $50-89 \%$ & $1(8.3 \%)$ & $13(29.5 \%)$ \\
\hline
\end{tabular}




\section{DISCUSSION}

After 3 months of therapy, the mean decrease in $\mathrm{HbA}_{1 \mathrm{c}}$ levels was $1.8 \%$ for all patients, higher in naive patients $(2.3 \%)$ than in previously treated patients $(1.3 \%)$. These results were consistent with the results of Scholz et al. in more than 22.000 patients with type-2 DM. ${ }^{4}$ However, the variation was large, in some patients $(17.9 \%)$ the $\mathrm{HbA}_{1 \mathrm{c}}$ levels were actually increased. These increased $\mathrm{HbA}_{1 \mathrm{c}}$ levels were found in 4 naive patients $(15.4 \%)$, and in 6 previously treated patients $(20 \%)$.

Based on initial BMI, the mean decrease in $\mathrm{HbA}_{1 \mathrm{c}}$ levels was $1.3 \%$ for normal weight patients, and $2.4 \%$ for obese patients. These results were also consistent with the findings of Scholz et al. ${ }^{4}$ For overweight patients, the mean decrease was only $0.9 \%$, it may be due to the small sample (only 10 patients).

The doses of glimepiride were not different in treatmentnaive patients and in previously treated patients, either the initial dose $(2.0 \mathrm{mg})$ or the final dose $(2.3 \%)$.

The mean decrease in FBG levels after 3 months of therapy was $54 \mathrm{mg} / \mathrm{dL}$ for all patients, and higher in naive patients $(83 \mathrm{mg} / \mathrm{dL})$ than in previously treated patients $(30 \mathrm{mg} / \mathrm{dL})$. Again, the variation was large, with some patients had increased FBG levels. The increased FBG levels were detected in 11 patients among the whole group of patients (19.6\%), in 5 naive patients $(19.2 \%)$, and in 6 previously treated patients $(20 \%)$.

The initial BMI had no effect on the mean decrease of FBG levels, which was $59 \mathrm{mg} / \mathrm{dL}$ in normal weight patients and $60 \mathrm{mg} / \mathrm{dL}$ in obese patients.

Treatment with insulin or insulin secretagogue is often associated with weight gain. Glimepiride, however, has been associated with weight neutrality or even weight loss in a number of trials. ${ }^{4}$

In the present study, a mean weight gain of $0.9 \mathrm{~kg}$ for all patients $(n=50)$ was noted. These results suggested that glimepiride, just like other insulin secretagogue, was associated with weight gain, although in the present study, due to the large variation, the increase in body weight was not statistically significant.

In the present study, after 3 months of therapy, glimepiride monotherapy achieved target $\mathrm{HbA}_{1 \mathrm{c}}(<7 \%)$ in 12 patients from a total of 56 patients $(21.4 \%)$. In 26 naive patients, 5 patients reached target $\mathrm{HbA}_{1 \mathrm{c}}(19.2 \%)$, while in 30 previously treated patients, 7 patients reached target $\mathrm{HbA}_{1 \mathrm{c}}(23.3 \%)$. The target FBG $(<120 \mathrm{mg} / \mathrm{dL})$ was reached by 10 patients among the total of 56 patients receiving glimepiride monotherapy for 3 months (18\%). In 26 naive patients, 6 patients reached the target FBG (23\%), and in 30 previously treated patients, 4 patients reached target FBG (13.3\%). This low rate in achieving the target $\mathrm{HbA}_{1 \mathrm{c}}$ and $\mathrm{FBG}$ in present study may be due to the short duration of study (3 months), high baseline values, and lack of dose escalation. Although the percentage of patients reaching target FBG was unexpectedly small (only 18\%), but the proportion of success in treatment-naive patients and in previously treated patients was as expected. On the contrary, the proportion of reaching target $\mathrm{HbA}_{1 \mathrm{c}}$ in treatmentnaive patients and in previously treated patients was unexpected, also among patients with baseline $\mathrm{HbA}_{1 \mathrm{c}}$ $7-10 \%$, which may be due to chance, considering the small number of patients. In the present study, the dose escalation was only until $4 \mathrm{mg}$ in some patients due to the investigators' fear of hypoglycemia considering the short duration of study (only 3 months) although no hypoglycemia was reported during the study.

There were various reasons for not reaching the target blood glucose, but the predominant reason was poor diabetic education (in 55\% of all patients). There may be some correlation between this poor diabetic education with the poor formal education received by most of our subjects. The major contribution, however, rested with the treating physicians, who did not spend enough time to explain the hazards of having poor diabetic control, due to resource constraint. "Dosage not optimum" was reported for $34 \%$ of the patients. The mean dose of Glimepiride at the end of the study was relatively low at $2.4 \mathrm{mg}$ for patients who had not achieved target $\mathrm{HbA} 1 \mathrm{c}$, with room for further dose escalation.

As expected, patients who reached good diabetic control (reached target $\mathrm{HbA}_{1 \mathrm{c}}$ ) also had good compliance in taking glimepiride. Around $90 \%$ of these patients showed $>90 \%$ compliance in taking glimepiride every month during this 3 months of therapy. Only around $70 \%$ of patients who did not achieve good blood glucose control showed $>90 \%$ compliance in taking glimepiride.

There was no adverse event found during this 3 months monotherapy with glimepiride. There were 18 patients lost to follow-up, but there was no explanation of the reason in the case report forms. Hypoglycemia, the mostly reported adverse reaction after glimepiride, was not reported in the present study. It may due to the low dose used in this study, in which the highest dose was 
only $4 \mathrm{mg}$ daily, whilst the maximum dose permitted is $8 \mathrm{mg}$. $^{7}$ More importantly, however, glimepiride is well known to cause a lower incidence of hypoglycemia compared to other sulfonylureas. ${ }^{1,2,8-10}$

Inconclusion, Glimepiride monotherapy in the present observational study in daily practice for 3 months was shown to be effective in reducing $\mathrm{HbA}_{1 \mathrm{c}}$ and FBG levels, especially in treatment-naive patients. However, the variations were large and the percentages of patients achieving good blood glucose control (target $\mathrm{HbA}_{1 \mathrm{c}}$ and target FBG) were small, which may be due to the short duration of study, high baseline values, and conservative dose escalation. Contrary to the previous studies, glimepiride treatment in the present study was associated with weight gain, although not statistically significant.

No adverse event was found in the present study with small number of patients and relatively low dosage of glimepiride.

\section{Acknowledgements}

We would like to thank the study patients for their participation and PT Aventis Pharma, sanofi-aventis Group for supporting the study.

\section{REFERENCES}

1. Langtry HD, Balfour JA. Glimepiride: a review of its use in the management of type 2 diabetes mellitus. Drugs. 1998; 55 (4): 563-84.
2. McCall AL. Clinical review of glimepiride. Exp Opin Pharmacother. 2001; 2(4): 699-713.

3. Kabadi MU, Kabadi UM. Effects of glimepiride on insulin secretion and sensitivity in patients with recently diagnosed type 2 diabetes mellitus. Clin Ther. 2004; 26(1): 63-9.

4. Scholz GH, Schneider K, Knirsch W, Becker G. Efficacy and tolerability of glimepiride in daily practice: a non-interventional observational cohort study. Clin Drug Invest. 2001; 21 (9): 597-604.

5. Tsunekawa T, Hayashi T, Suzuki Y, Matsui-Hirai H, Kano $\mathrm{H}$, Fukatsu A, et al. Plasma adiponectin plays an important role in improving insulin resistance with glimepiride in elderly type-2 diabetic subjects. Diab Care. 2003; 26(2):285-9.

6. Koshiba K, Nomura M, Nakaya Y, Ito S. Efficacy of glimepiride on insulin resistance, adipocytokines, and atherosclerosis. J Med Invest. 2006; 53: 87-94.

7. Amaryl Prescribing Information

8. Dills DG, Schneider J. Clinical evaluation of glimepiride versus glyburide in NIDDM in a double-blind comparative study. Glimepiride/Glyburide Research Group. Horm Metab Res. 1996; 28(9): 426-9.

9. Draeger KE, Wernicke-Panten K, Lomp HJ, Schuler E, Rosskamp R. Long-term treatment of type-2 diabetic patients with the new oral antidiabetic agent glimepiride (Amaryl): a double-blind comparison with glibenclamide. Horm Metab Res. 1996; 28(9): 419-25.

10. Massi-Benedetti M. Glimepiride in type 2 diabetes mellitus: a review of the worldwide therapeutic experience. Clin Ther. 2003; 25: 799-816. 